\title{
LEGISLATIVE NEWS
}

\section{IN FECTION \\ CONTIROL.}

\section{Health Care Budget}

Congress seems likely to go along with most of the massive Budget cuts in the health field asked for by President Reagan in the budget message sent to Congress. The legislators seem to view Reagan's election as a mandate from the people to cut Federal spending. All of the House and a third of the Senate must run for re-election in 1982 and are wary of being labeled as "big spenders."

The President has made sweeping reductions in Federal health programs for fiscal 1982-the government accounting year beginning next October l. He asked for a consolidation of some 40 health and social service categorical grant programs into block grants in what is envisioned as a substantial reduction in the amount of money spent. Medicaid spending would be reduced by means of an interim cap on Federal participation. This would be followed by comprehensive legislation to overhaul the Title 19 entitlement program.

Reagan proposes to cut back spending for biomedical research under the aegis of the National Institutes of Health. In the past, this spending had been considered untouchable.

Eight Public Health Service hospitals would be closed, as well as $\mathbf{2 9}$ clinics that now provide free medical care to merchant seamen and certain other population groups.

The program would end large general subsidies for the training of physicians and other health professionals in favor of more targeted support for the education of those who will serve areas of manpower shortages.

Federal subsidies for the development of health maintenance organizations would be eliminated.

No new National Health Service Corps scholarships would be authorized, but placement services would be continued through the 1990s, when present students complete their training and begin obligatory service.

Federal health planning and Professional Standards Review Organization programs would be phased out over the next two years.

The Reagan program announced recently is just the first round in a series of budget cutting initiatives planned by the Administration, according to Office of Management and Budget Director David Stockman. Among future budget changes could be some form of a competition-based health care delivery system, which was proposed by Stockman when he was a member of Congress. Stockman told the senators that the Administration could propose "basic structural reform to our system of health care reimbursement," which, he said, could save "literally billions of dollars."

Of all of Reagan's proposed cuts in health programs, the Federal cap on Medicaid reimbursement promises to be the most difficult to have approved by Congress. The plan has already provoked several Democrats to speak out publicly, while several Republicans have begun looking for alternatives to the Reagan plan. Chairman Robert Dole ( $R, K N)$ of the Senate Finance Committee is known to be skeptical of the cap idea, though he has not voiced outright opposition to it. House Commerce Health Subcommittee chairman Henry Waxman (D, CA) was particularly critical of the cap on Medicaid, saying it would "lead to a loss of health coverage for many medically needy families."

\section{Nursing Home Patients' Rights}

The General Accounting Office has released its required analysis of the Carter Administration's proposed nursing home patients' right rulebut too late to save the proposal.

The GAO report was delayed by House Minority Leader Robert Michel (R, IL) in order to allow the Reagan Administration time to study the proposal. HHS Secretary Richard Schweiker has withdrawn the rule. The GAO report questioned estimates of the costs of implementation. 